\title{
Comparison of sedimentary processes on adjacent passive and active continental margins offshore of SW Taiwan based on echo character studies
}

\author{
J.-K. Chiu and C.-S. Liu \\ Institute of Oceanography, National Taiwan University, Taipei, Taiwan, ROC
}

\begin{abstract}
Echo character recorded on Chirp sub-bottom sonar data from offshore of SW Taiwan was analysed to examine and compare the sedimentary processes of adjacent passive and active continental margin settings. Seafloor echoes in the study area are classified into four types: (1) distinct echoes, (2) indistinct echoes, (3) hyperbolic echoes and (4) irregular echoes. Based on the mapped distribution of the echo types, the sedimentary processes offshore of SW Taiwan are different in the two tectonic settings. On the passive South China Sea (SCS) margin, slope failure is the main process on the upper continental slope, whereas turbidite deposits accumulate in the lower continental slope. In contrast, the submarine Taiwan orogenic wedge is characterized by fill-and-spill processes in intraslope basins on the upper slope, and mass-transport deposits are observed in the canyons and on the lower Kaoping slope. This difference is largely caused by the huge influx of terrigenous sediments into the submarine Taiwan orogenic wedge compared with the passive SCS continental margin. In the latter, loading and movement of the Taiwan orogenic wedge has had a significant effect on the seafloor morphology and has triggered retrogressive failures. Gas hydrate dissociation may have enhanced the slope failure processes at some locations.
\end{abstract}

\section{INTRODUCTION}

Investigations of sedimentary processes have been conducted extensively on both passive (e.g. Chough et al., 2002; Casas et al., 2003; Mienert \& Weaver, 2003) and active continental margins (e.g. MacDonald, 1993; Whitmore et al., 1999; Orpin, 2004; Yu \& Huang, 2006). However, few studies have focused on direct comparison of the sedimentary processes on adjacent passive and active continental margins, as the present study does. For example, McAdoo et al. (2000) analysed submarine landslides in both western (active) and eastern (passive) US continental slopes, but the four areas they studied are far apart; thus, each area may have its own controlling factors on sedimentary processes besides the different tectonic settings.

The area offshore of SW Taiwan is the place where the passive South China Sea (SCS) continental margin meets the Taiwan orogenic wedge (Fig. 1). Active arc-continent collision has created the high mountains of Taiwan (Teng, 1990; Huang et al., 1999). Frequent earthquakes and high precipitation during typhoon seasons have caused rapid mass-wasting and high sediment output to the seas around Taiwan (Hovius et al., 2000; Dadson et al., 2003). For example, Damuth $(1979,1980 a)$ described fields of large migrat-

Correspondence: Prof. Char-Shine Liu, Institute of Oceanography, National Taiwan University, Taipei, Taiwan, ROC. E-mail: csliu@ntu.edu.tw ing sediment waves on the seaward wall of the Manila Trench, which were deposited by turbidity currents transporting large volumes of sediments from Taiwan. Thus, the area offshore of SW Taiwan is an ideal place to study and compare sedimentary processes in continental margins containing both passive and active tectonic environments.

During the past 50 years, seabed imaging and characterization using very high-resolution seismic (echo character) data have provided critical information that helps to understand the complex processes of transporting sediments from shore, across the continental margin, to the deep ocean basin. Very high-resolution sub-bottom profiler data (mainly $3.5 \mathrm{kHz}$ and chirp sonar) have been routinely used to reveal the echo character (also termed seismic facies) of seafloor sediments to better understand the sedimentary processes in deep-sea environments (e.g. Damuth, 1975, 1980a; Damuth \& Hayes, 1977; Damuth et al., 1983; Gaullier \& Bellaiche, 1998; Lee et al., 2004; see Damuth, 1980b for a review), and more recently continental shelves (e.g. Chough et al., 2002; Shinn et al., 2007). These and other studies have demonstrated that distinct types of echoes can be identified on the sub-bottom profiles, and classified and mapped. These different types of echo character reflect the combined effects of seafloor topography, subsurface geometry and sediment types and processes (Damuth, 1980b; Chough et al., 2002; Lee et al., 2005).

Damuth (1979, 1980a) studied the Quaternary sedimentation processes of the SCS on a regional scale using 


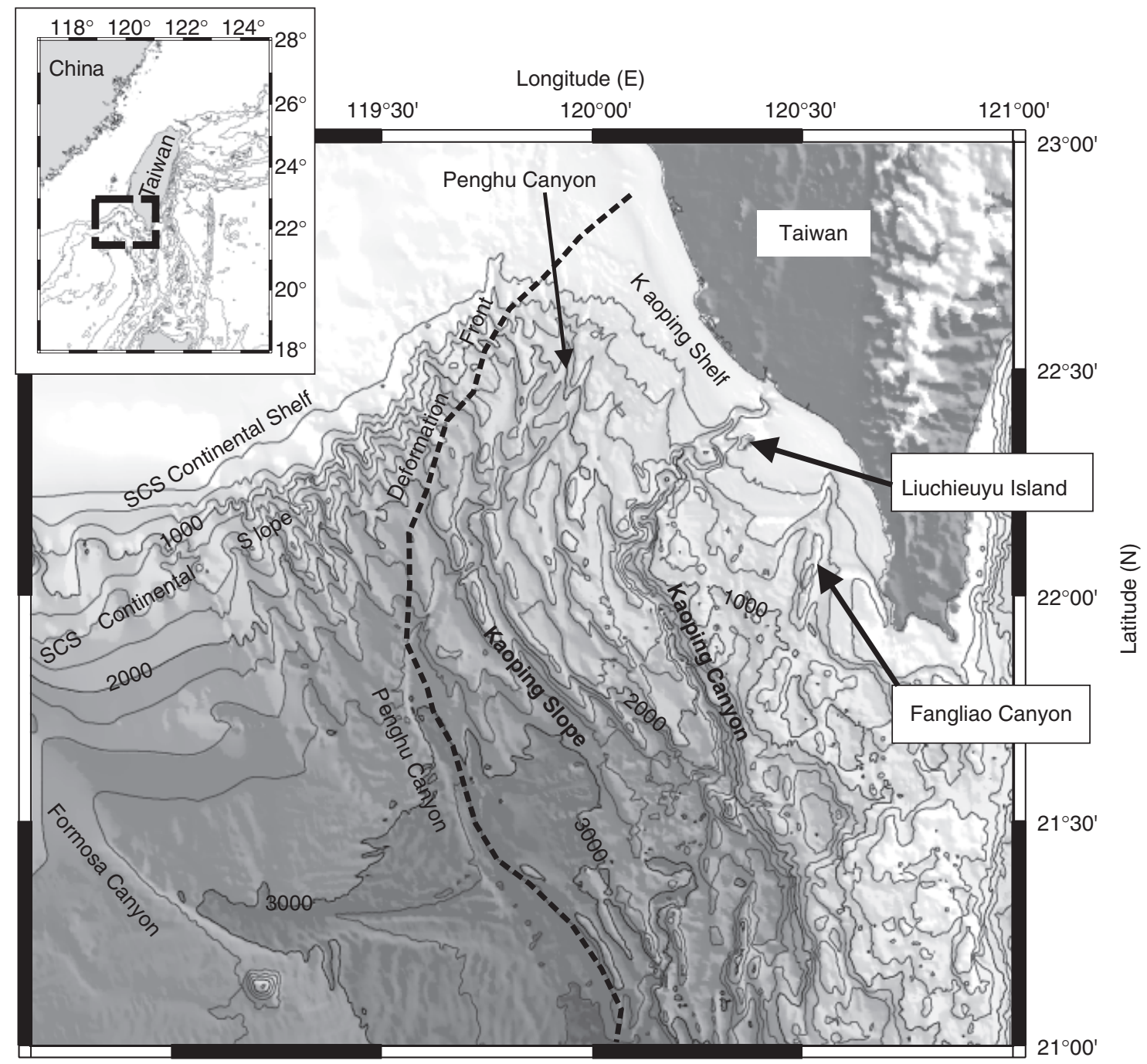

Fig. 1. Geological setting of the study area offshore SW Taiwan. The black dashed line represents the deformation front separating the passive South China Sea (SCS) continental margin from the active submarineTaiwan orogenic wedge. Bathymetry contours are at $250 \mathrm{~m}$ intervals. The box inset shows the map area.

echo-character mapping and piston cores. These studies included the slope and basin floor in most of the present study area, but data were very widely spaced. In particular, the studies showed that large volumes of sediment derived from Taiwan were transported by turbidity currents down the Manila Trench and were deposited as high migrating sediment waves on the western wall of the trench. Yu \& Lee (1992) used $3.5 \mathrm{kHz}$ sub-bottom profile data to study the echo characteristics of the shelf and upper slope transition off SW Taiwan. They suggested that shallow-marine sedimentation predominates on the Kaoping shelf and in the southern Taiwan Strait where currents and tides have modified the relict Late Pleistocene sands and Holocene muds. The continental slope in their study area is dominated by downslope processes that change laterally. However, their study was limited to the shelf and upper slope area, where the water depth is generally $<1000 \mathrm{~m}$.

Since 2002, densely spaced multichannel seismic reflection data, together with chirp sonar profile data, have been collected in a broad area offshore of SW Taiwan (Fig. 2) for gas hydrate investigation (Liu et al., 2006). These data sets cover the area where the active Taiwan orogenic wedge encroaches on the rifted SCS continental margin, thus providing good opportunities to investigate the structural variations and sedimentary processes in both passive and active tectonic environments. A study of tectonic/structural features of the region is reported in another paper (Lin et al., accepted). Here, sedimentary processes of the region are examined based on the chirp sonar and seismic reflection data. We first give an overview of the sedimentary processes offshore SW Taiwan, mainly based on seismic images and seafloor echo characteristics. A map of echo characteristics within the study area is constructed that reveals different sedimentary processes in different tectonic and sedimentary environments. Finally, we discuss the possible mechanisms of the different sedimentary processes and their geological implications. 
Longitude $(E)$

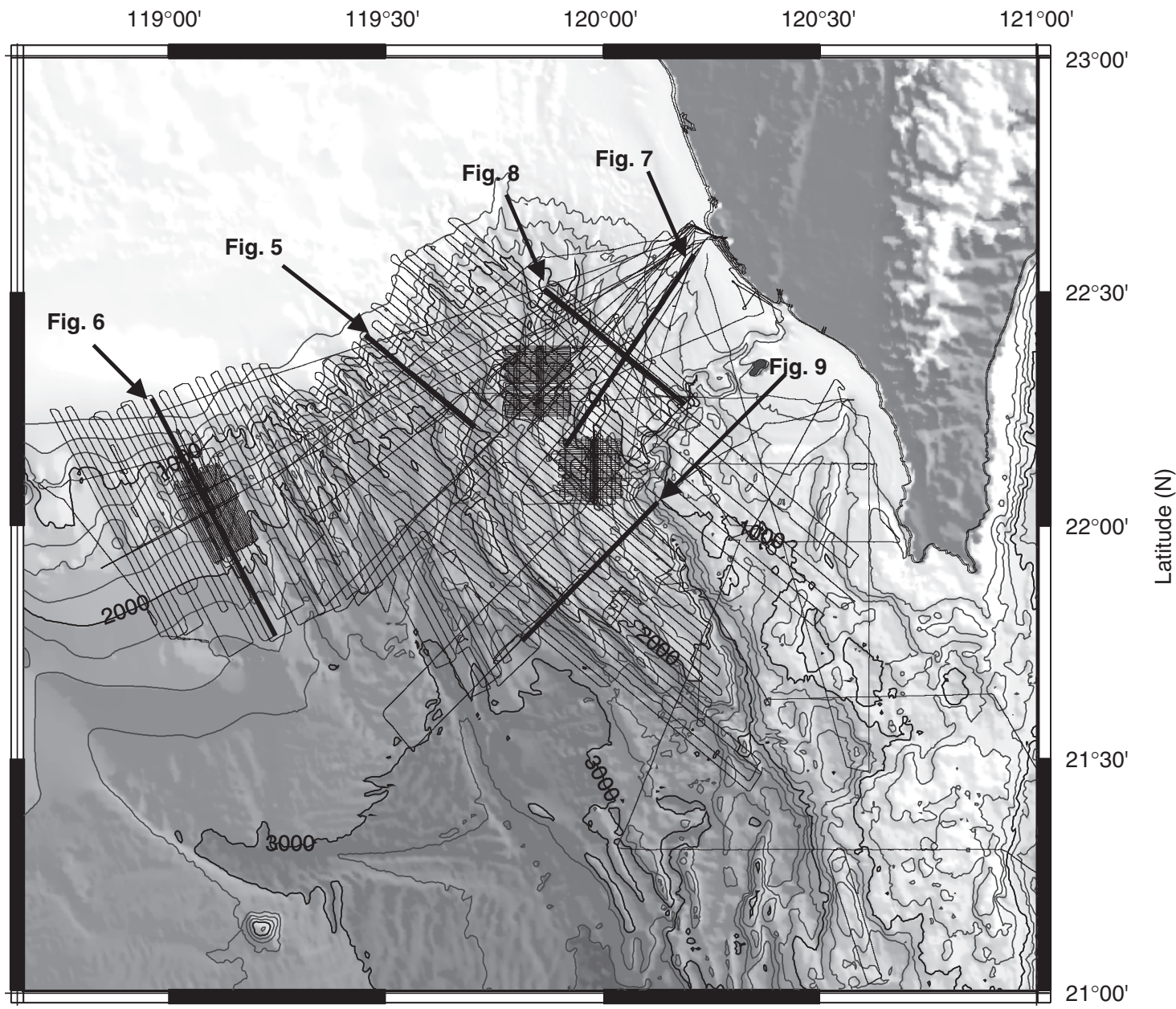

Fig. 2. Location map of the chirp sonar profiles used in this study, shown as thin lines. Thick lines show the locations of the profiles shown in the figures as labelled. The bathymetry map is the same as in Fig. 1.

\section{GEOLOGICAL BACKGROUND}

The area offshore of SW Taiwan is where two distinctive tectonic provinces, the passive SCS continental margin on the west and the Luzon subduction complex on the east, meet (Liu et al., 1997, 2004; Huang et al., 1999) (Figs 1 and 2). The structural features are quite different in these two tectonic provinces: ENE-WSW-trending normal faults are observed in the passive continental margin, whereas fold-and-thrust structures dominate in the orogenic wedge (Liu et al., 1997). The boundary of these two provinces is the deformation front, which extends northward from the northern end of the Manila Trench to the Tainan area onshore Taiwan (Liu et al., 2004). In addition, complex systems of mud diapirs are observed in the Kaoping shelf and the upper Kaoping slope (Sun \& Liu, 1993).

Morphologically, the passive SCS continental margin consists of a shelf, slope and rise (Liu et al., 1998). The SCS continental shelf is the southwestward extension of the Taiwan Strait shelf. It is shallow ( $<240 \mathrm{~m}$ deep), relatively flat and has a width of about $200 \mathrm{~km}$. The SCS continental slope is incised by a series of submarine canyons and gullies. East of the deformation front, the submarine Taiwan orogenic wedge consists of the Kaoping shelf and Kaoping slope. The Kaoping shelf is a narrow and shallow shelf that is the seaward extension of the coastal plain of SW Taiwan (Yu \& Wen, 1992). The Kaoping slope has a very irregular surface that can be divided into an upper slope domain and a lower slope domain (Reed et al., 1992; Liu et al., 1998). The former has four main NE-SWtrending submarine canyons, whereas the latter is characterized by closely spaced $\mathrm{N}-\mathrm{S}$ - to NW-SE-trending ridges and troughs formed by structural deformation (Yu \& Song, 2000).

The gradients of the seafloor in the study area vary from $2^{\circ}$ to $60^{\circ}$ (Fig. 3). Steep slopes characterize the side walls of most submarine canyons in both the orogenic wedge and the passive continental margin provinces. In the passive margin province, the upper continental slope is much steeper than the lower continental slope east of about $119^{\circ} 24^{\prime} \mathrm{E}$, but this is not the case further west (Fig. 3). In contrast, in the submarine Taiwan orogenic wedge province, the seafloor of the upper slope domain appears to be broad and gentle, except in submarine canyons, 


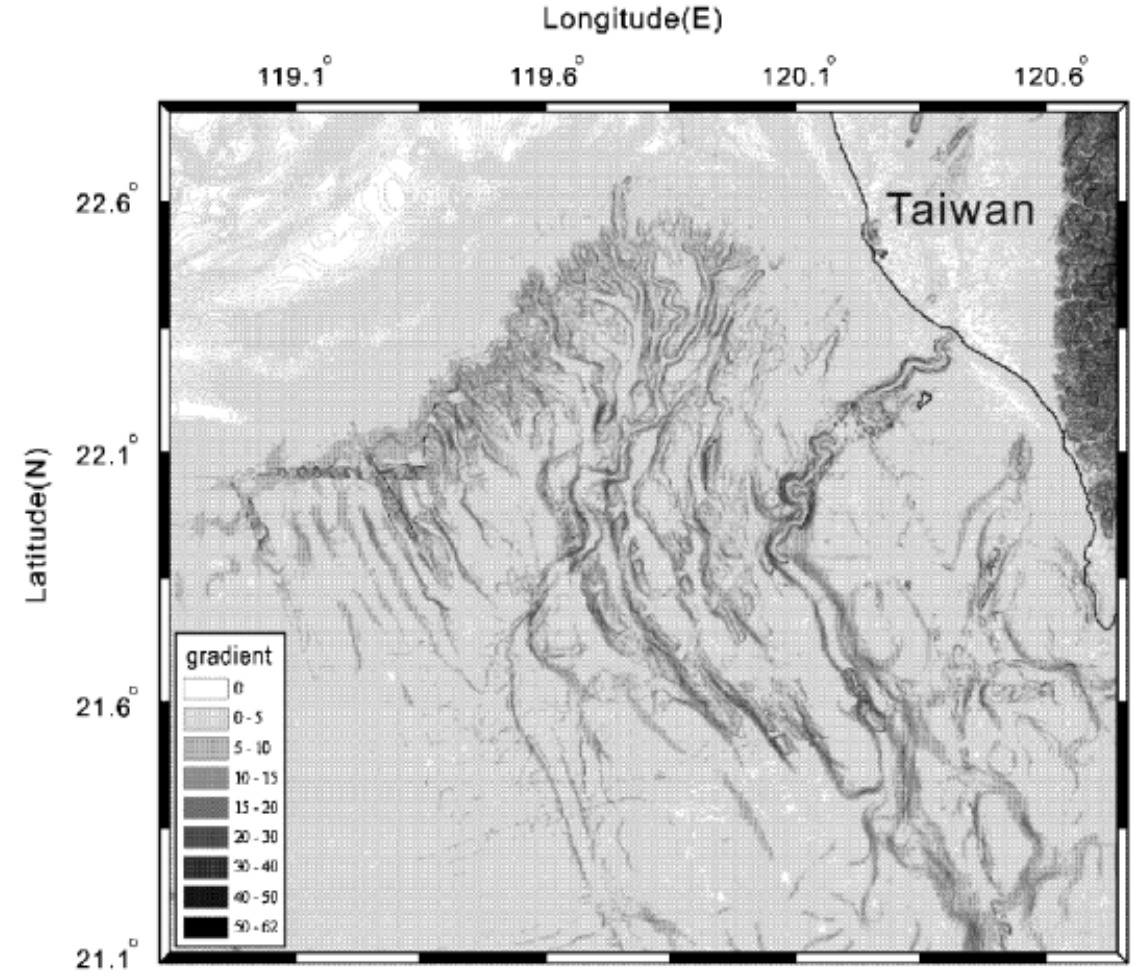

Fig. 3. Topographic gradient (slope) map of the study area. High gradients occur in the upper slope of the eastern portion of the passive SCS margin, and along submarine canyon walls and ridge flanks. SCS, South China Sea. whereas in the lower slope domain, steep slopes have been observed along the flanks of many anticlinal ridges.

\section{DATA PREPARATION}

High-resolution bathymetry, chirp sub-bottom profile and seismic reflection data were used in this study to examine seafloor morphology and sedimentary processes. Regional bathymetry (Fig. 1) is based on the $500 \mathrm{~m}$ grid TAIDBMv6 DTM data set (Liu et al., 1998), with a recent improvement from newly collected single-beam bathymetric data from the SCS continental margin west of $119^{\circ} \mathrm{E}$ (Liu, 2007). Swath bathymetry data collected by the R/V Atalante during the 1996 ACTsurvey (Lallemand et al., 1997 ) provided high-resolution ( $100 \mathrm{~m}$ grid) bathymetric coverage in the central portion of the study area where the SCS continental margin meets the Taiwan orogenic wedge (Liu et al., 2004). Bathymetry maps in this paper were generated using GMT (Wessel \& Smith, 1993).

Approximately $9948 \mathrm{~km}$ of chirp sub-bottom profile data have been analysed (Fig. 2). These data were collected by the R/V Ocean Researcher 1 (OR1) during seven cruises from 2002 to 2006 in an area from $21^{\circ} 30^{\prime}$ to $22^{\circ} 30^{\prime} \mathrm{N}$ and $118^{\circ} 40^{\prime}$ to $120^{\circ} 35^{\prime} \mathrm{E}$. Most of the survey lines are oriented in a NW-SE direction with a line spacing of about $1.86 \mathrm{~km}$. The sub-bottom profile data were collected by a hull-mounted Bathy-2000P chirp sonar system. An $8 \mathrm{kHz}$ bandwidth FM chirp waveform was used during the survey. This system can provide high-resolution seafloor reflection data with an $\sim 8 \mathrm{~cm}$ vertical resolution and bottom penetration of up to $200 \mathrm{~m}$ under ideal conditions.
Selected multi-channel seismic (MCS) reflection profiles were used in this study to reveal the sedimentary structures of the region. The data were collected using a high-resolution MCS reflection system. A solid streamer of 48 or 24 channels with a $12.5 \mathrm{~m}$ channel interval was used to receive seismic signals, and the seismic source was an airgun array consisting of three Bolt airguns with a total volume of $475-775$ in $^{3}$, depending on the sizes of the air guns used on different cruises. The guns were fired every $10 \mathrm{~s}$, which gives a nominal shot interval of $25 \mathrm{~m}$. All the MCS data were processed at the Institute of Oceanography, National Taiwan University, using the ProMAX and SIOSEIS seismic data processing systems. The typical seismic data processing sequence comprised trace editing, spiking noise removal, water column mute, geometry setup, amplitude compensation, predictive deconvolution, band-pass filtering, velocity estimation, normal moveout correction, CMP stacking and F-K time migration.

\section{ECHO CHARACTER CLASSIFICATION AND MAPPING}

Using the chirp sonar profile data (Fig. 2), we have identified and classified eight discrete echo types on the basis of reflection characters (e.g. clarity, continuity, amplitude and geometry of bottom and sub-bottom echoes). Our classification is modified from Damuth $(1975,1980 \mathrm{a}, \mathrm{b})$ and $\mathrm{Yu}$ \& Lee (1992) to accommodate echo types observed in our study area. Four categories of echo types are recognized in this study: (1) Distinct echoes (Types I-1 and I-2), (2) Indistinct echoes (Types II-1 and II-2), (3) Hyperbolic 


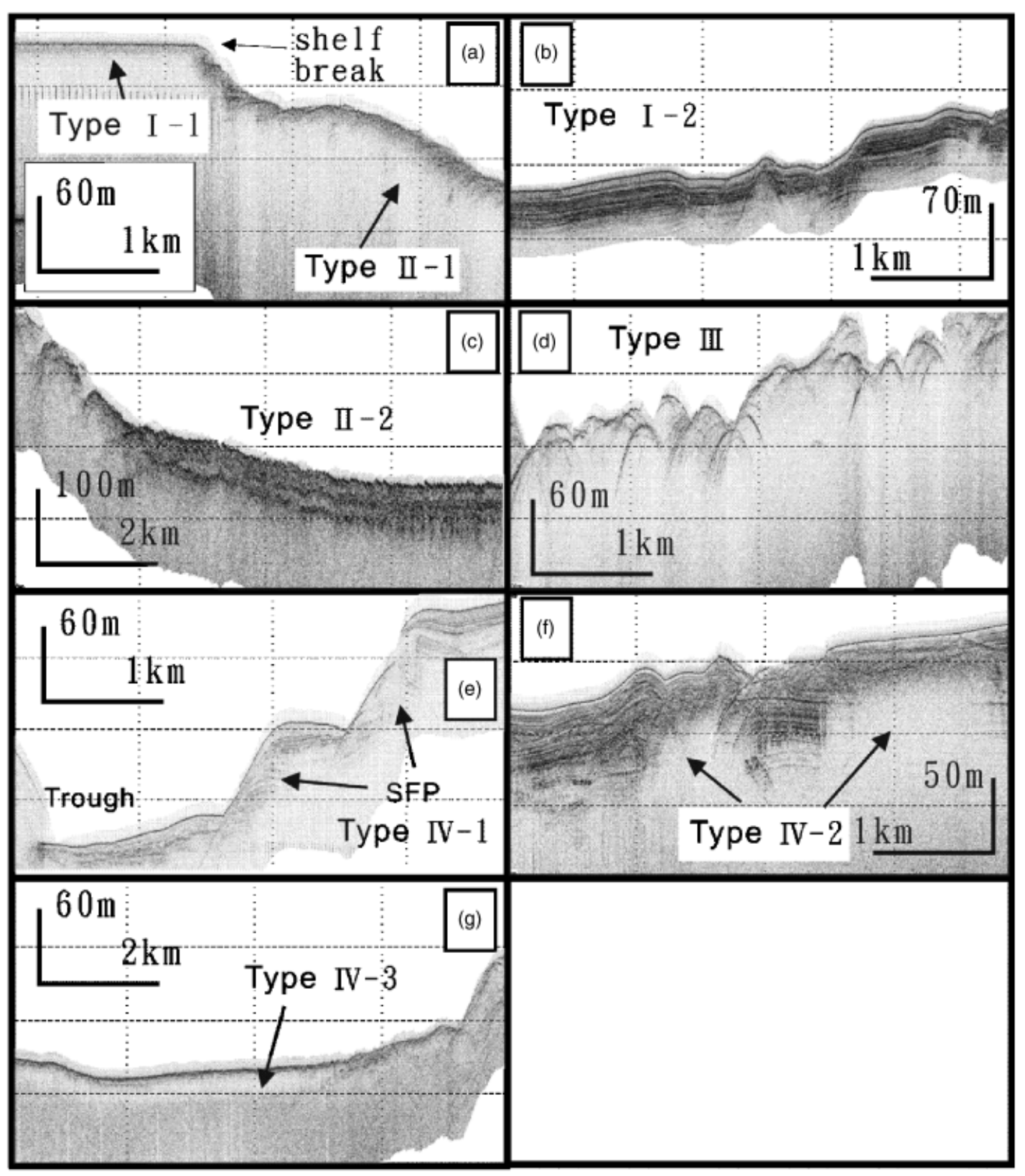

Fig. 4. Chirp sonar characters of different echo types. (a) Distinct bottom echo with either no or a few sub-bottom reflectors (type I-1) and indistinct bottom echo and bushy, prolonged sub-bottom echoes (type II-1). (b) Distinct bottom echo with continuous, parallel internal reflectors (type I-2). (c) Wavy, prolonged sub-bottom echoes (type II-1). (d) Large single or irregular overlapping hyperbolae with widely varied vertex elevations (type III-2). (e) Several slope failure planes (SFP) within a short distance (type IV-1). (f) Some blanking zones interrupt the continuous reflectors (type IV-2). (g) Sea floor transparent blanketing layer. (type IV-3).

echoes (Type III) and (4) Irregular echoes (Types IV-1, IV-2 and IV-3) (Fig. 4). We describe each echo type in detail below, and Table 1 summarizes the description, occurrence and geological interpretation of each echo type.

\section{Distinct echoes}

Type I-1

Echoes show a sharp seafloor reflection, with a few to no sub-bottom echoes (Fig. 4a). The seafloor is generally flat or gently undulating, with a slightly irregular relief. Type
I-1 echoes occur mostly on the continental shelf (Figs 5-7 and 10) where coarse-grained, sandy deposits are common (Chen, 1983; Lee et al., 2004).

\section{Type I-2}

Echoes are characterized by distinct bottom echoes with continuous, parallel, generally conformable sub-bottom reflections (Fig. 4b). The seafloor is generally flat to undulating or rolling. Penetration ranges from 40 to $100 \mathrm{~m}$. At a few locations, the continuous reflections are interrupted by 


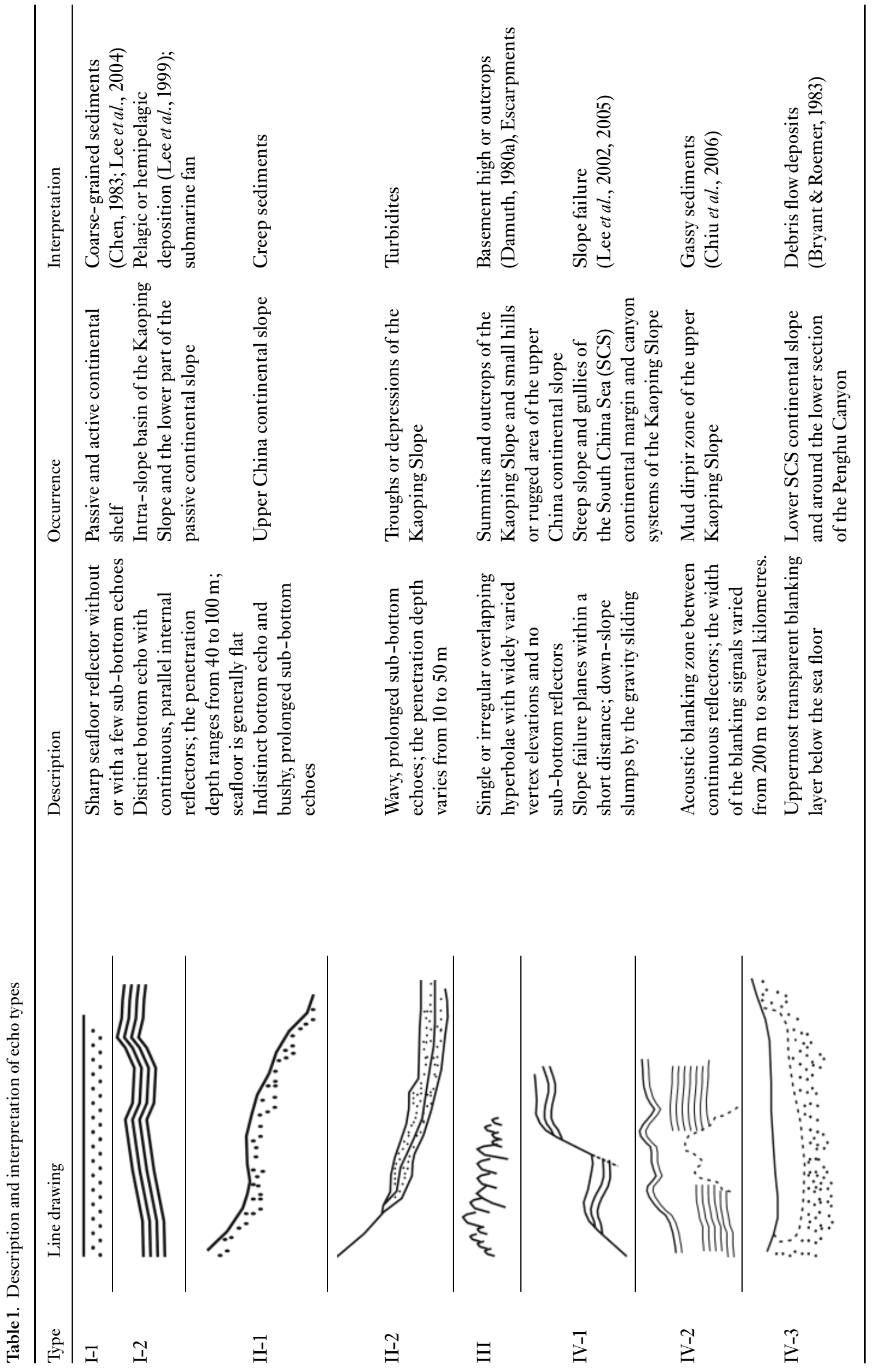



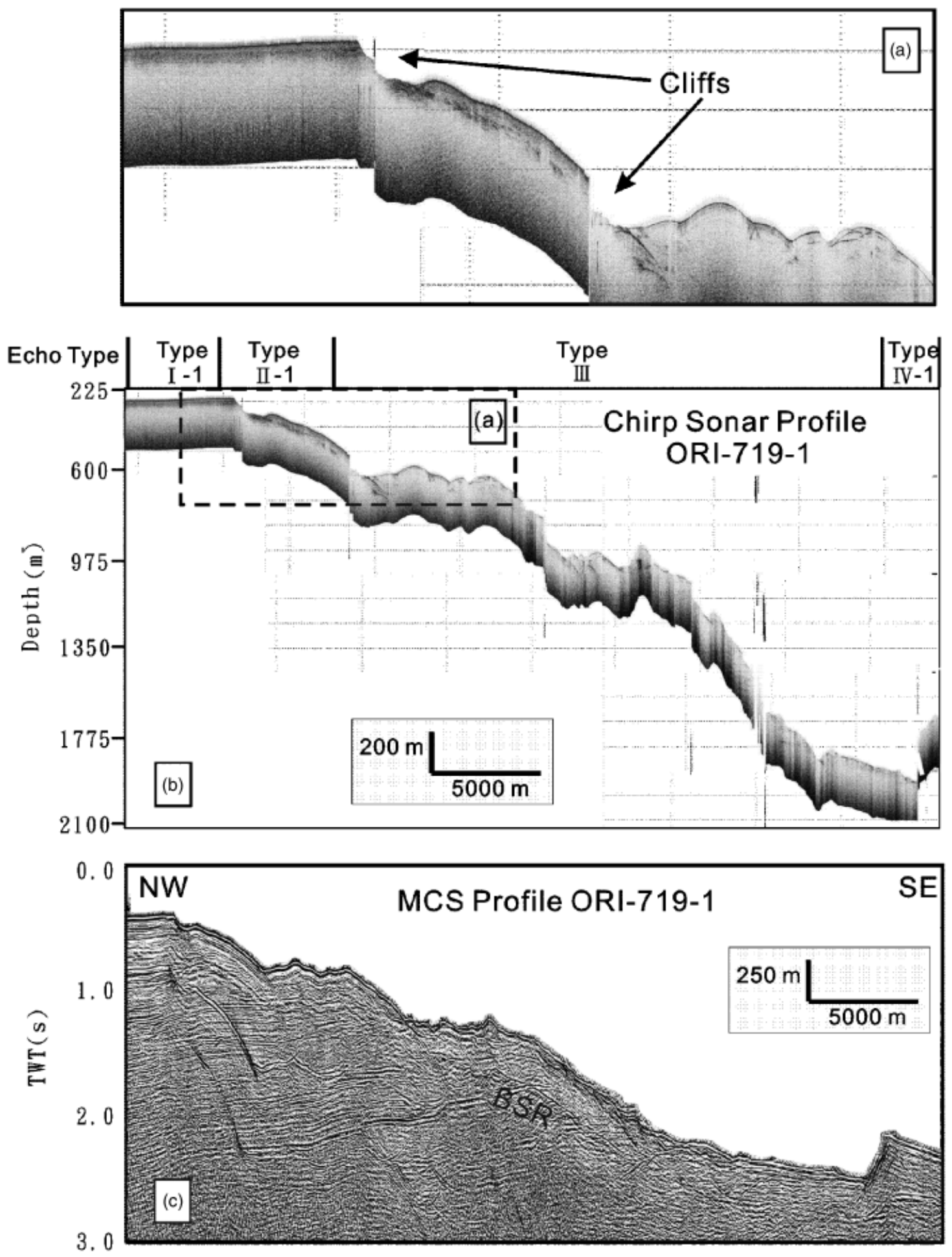

Fig. 5. Chirp sonar profile OR1-719-1 (b) and corresponding seismic reflection profile (c). The inset (a) shows an enlarged chirp sonar image of the selected section. This profile runs across the slope of the SCS passive margin (see Fig. 2 for profile location). The interpreted echo types and their respective extents along this profile are given above the chirp sonar profile. BSR, Bottom Simulating Reflectors; SCS, South China Sea.

faults or submarine mud volcanoes. Type I-2 echoes are mostly observed in the slope basins of the Kaoping slope and the lower part of the SCS continental slope (Figs 6-8 and 10). This echo type indicates persistent sedimentation.

\section{Indistinct echoes}

Type II-1

Echoes are characterized by indistinct bottom echoes with discontinuous, prolonged sub-bottom echoes (Fig. 4a). 
J.-K. Chiu and C.-S. Liu

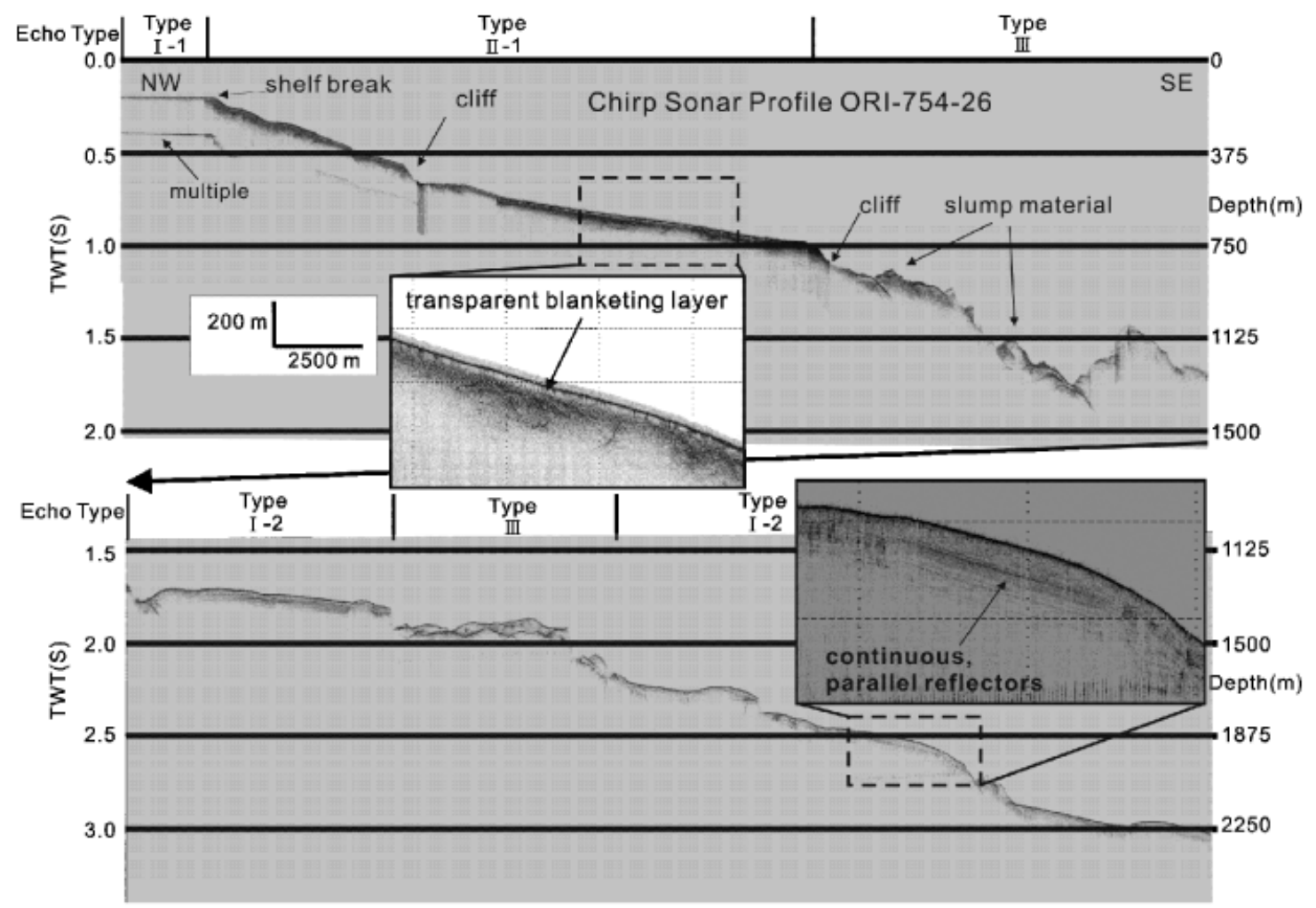

Fig. 6. Chirp sonar profile OR1-754-26. The insets show enlarged chirp sonar images of selected sections. The large arrow indicates where the upper profile connects to the lower profile. See Fig. 2 for profile location. The interpreted echo types and their respective extents along this profile are given above the chirp sonar profile.

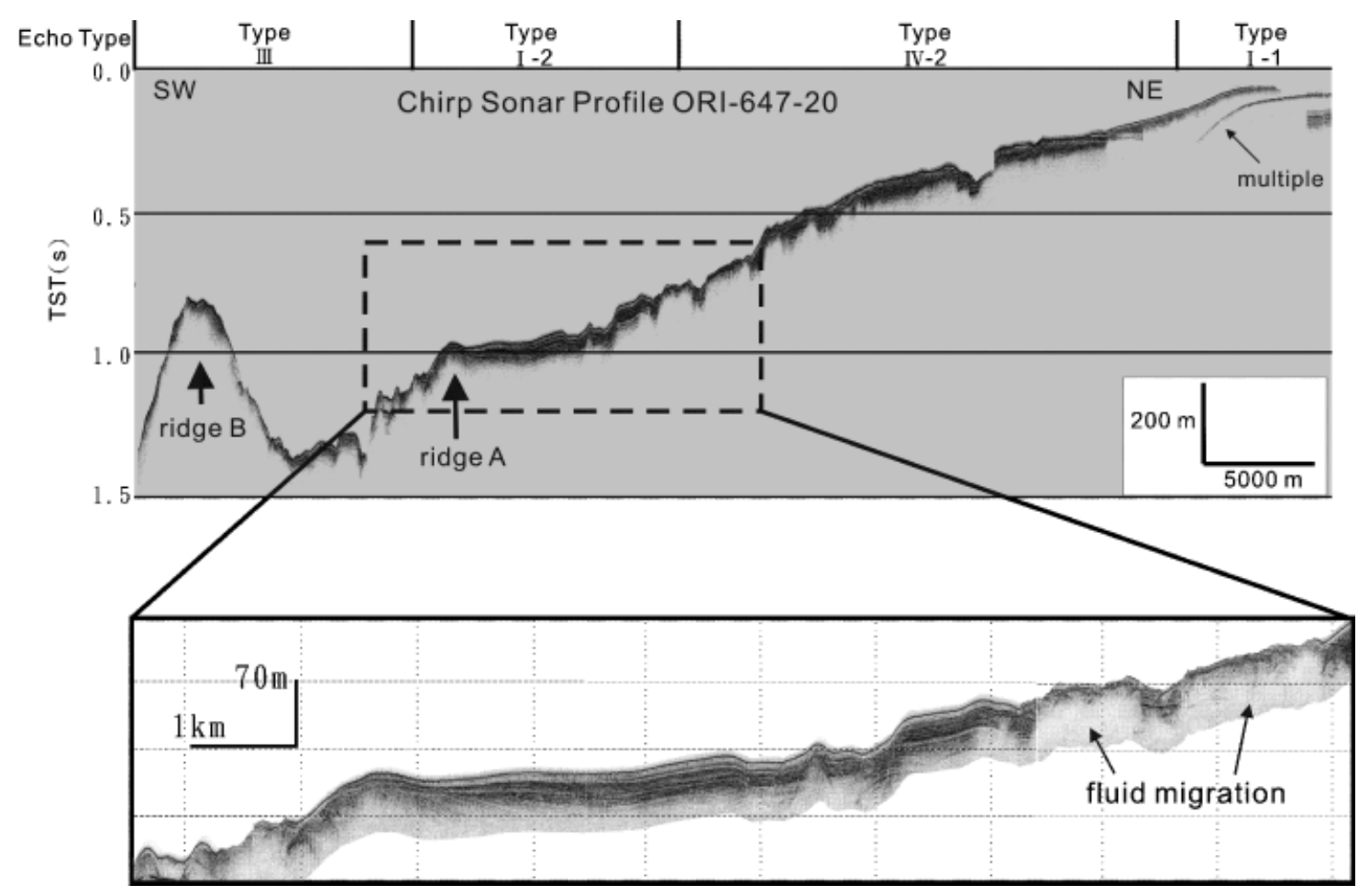

Fig. 7. Chirp sonar profile OR1-647-20. This profile runs across the upper Kaoping slope (see Fig. 2 for profile location). The inset shows the enlarged chirp sonar images of the sections indicated by the box where fill-and-spill features can be clearly seen. The interpreted echo types and their respective extents along this profile are given above the chirp sonar profile. 

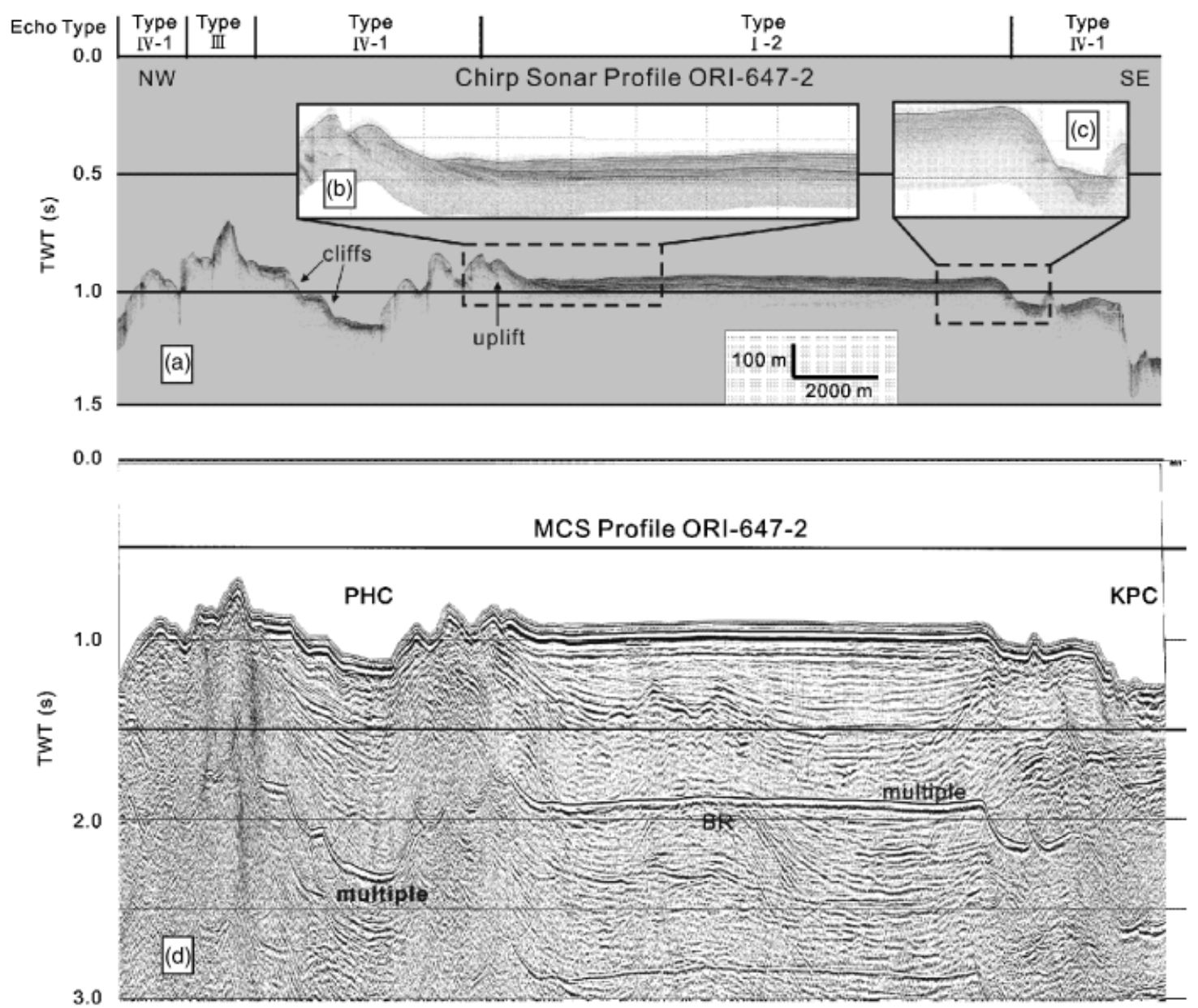

Fig. 8. Chirp sonar profile OR1-647-2 (a) and the corresponding seismic reflection profile (d). The NW-SE-trending profile lies near the mouth of the Kaoping River on the Kaoping slope (see Fig. 2 for profile location). Parallel, continuous reflectors that were bent by the growth of a structural ridge can be seen in inset (b). Inset (c) shows slope failure deposits of the Kaoping canyon (KPC) wall. The interpreted echo types and their respective extents along this profile are given above the chirp sonar profile. BR, Buried Ridge; PHC, Penghu canyon.

They are mainly recorded from the SCS continental slope with a relatively smooth seafloor (Figs 5, 6 and 10).

Type II-2

Echoes are characterized by indistinct to prolonged bottom echoes and continuous to discontinuous, prolonged sub-bottom echoes (Fig. 4c). Penetration varies from 10 to $50 \mathrm{~m}$. These echoes are generally observed in the troughs or the depressions of the slopes on both passive and active margins (Figs 9 and 10) and are interpreted as turbidites (Lee et al., 2002).

\section{Hyperbolic echoes}

Type III

Echoes are characterized by irregular single to overlapping hyperbolae with widely variable vertex elevations (Fig. 4d). This echo type shows no sub-bottom reflectors and is observed on records from small hills and other areas of rugged relief(Figs 7,9 and 10). Type III echoes are generally recorded from rugged basement highs or rock outcrops (Damuth, 1980a, b; Lee et al., 2002, 2005).

\section{Irregular echoes}

Type IV-1

Echoes show distinct bottom echoes with truncated or vended sub-bottom reflections beneath steeply dipping seafloor and conformable sub-bottom reflections beneath the adjacent flat seafloor (Fig. 4e). They occur on steep slopes or along canyon walls (Figs 5, 8 and 9). In some cases, the unconsolidated sediments near the seafloor were sheared and thinned along a slide plane.

\section{Type IV-2}

Echoes are characterized by the occurrence of acoustic blanking zones, which often interrupt the adjacent continuous reflectors (Fig. 4f). Type IV-2 echoes are interpreted as representing gassy sediments (Fig. 7), and the acoustic 


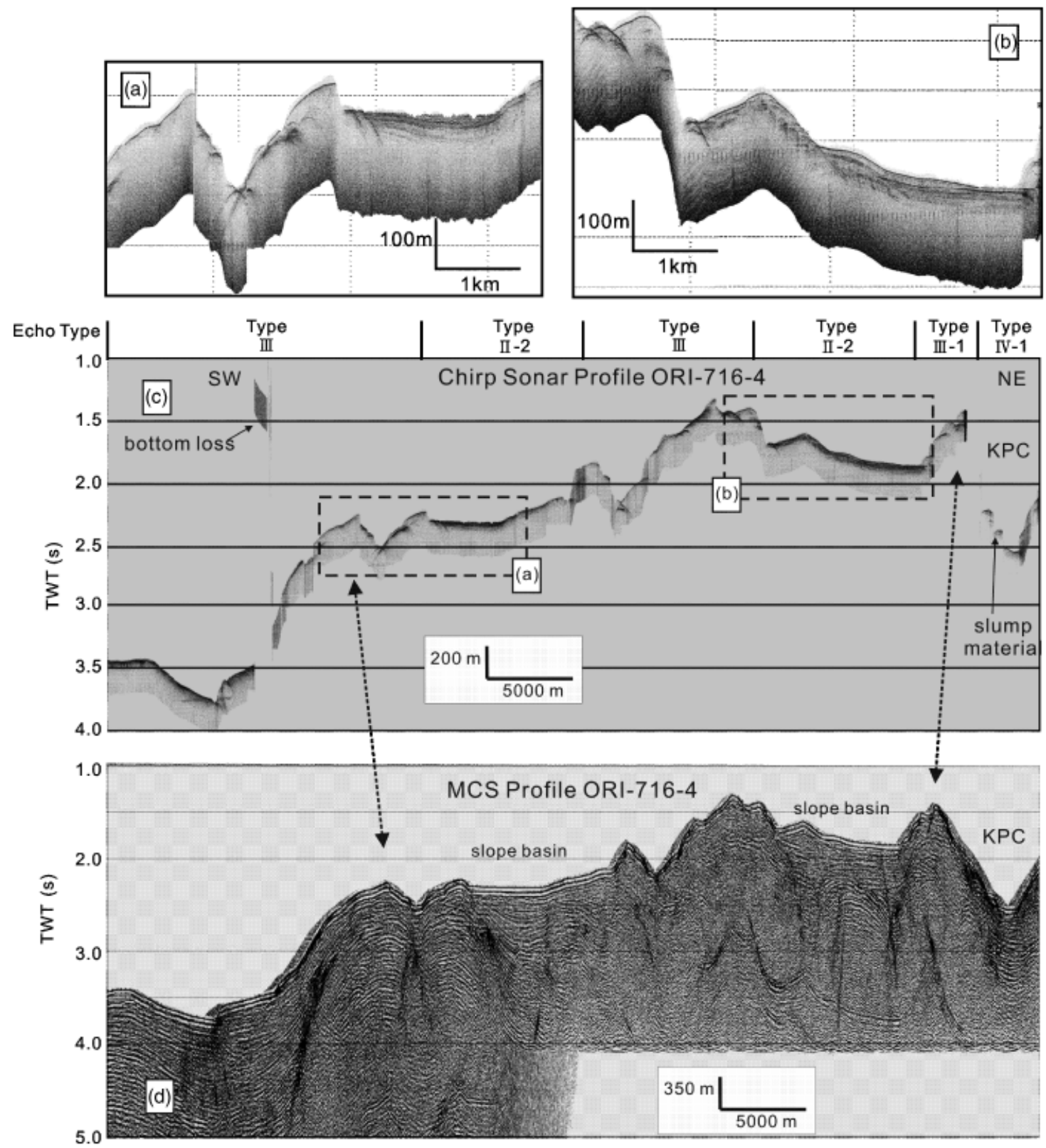

Fig. 9. Chirp sonar profile OR1-716-4 (c) and the corresponding seismic reflection profile (d). The NE-SW-profile goes from the Kaoping canyon to the lower Kaoping slope (see Fig. 2 for profile location). Echo characters of the slope basin deposits can be seen in the enlarged chirp sonar images in inset $(a, b)$. The interpreted echo types and their respective extents along this profile are given above the chirp sonar profile.

blanking is caused by an abrupt change of the reflection coefficient at the gas-filled sediment boundary. The width of the blanking zone varies from $200 \mathrm{~m}$ to several kilometres.

\section{Type IV-3}

These consist of sharp bottom echoes with a thin transparent or a non-reflective layer on top of a zone of indistinct to prolonged sub-bottom echoes (Fig. 4g). This echo type has been interpreted to represent debris flow deposits (Bryant \& Roemer, 1983).

\section{Echo character map}

A map showing the distribution of the different echo types was compiled to help define the sedimentary processes in the different tectonic and depositional environments in the study area (Fig. 10). For example, type I-1 echoes are distributed on the shelf areas of both the passive continental margin and the orogenic wedge provinces (Figs 5, 6 and 10), reflecting the sandy sediments that dominate shelf deposits. Type III echoes are limited to ridge summits and their steep flanks (Figs 7, 9 and 10). They reflect hard seafloor outcrops on ridge crests. Type IV-1 echoes are observed along the paths of submarine canyons and 


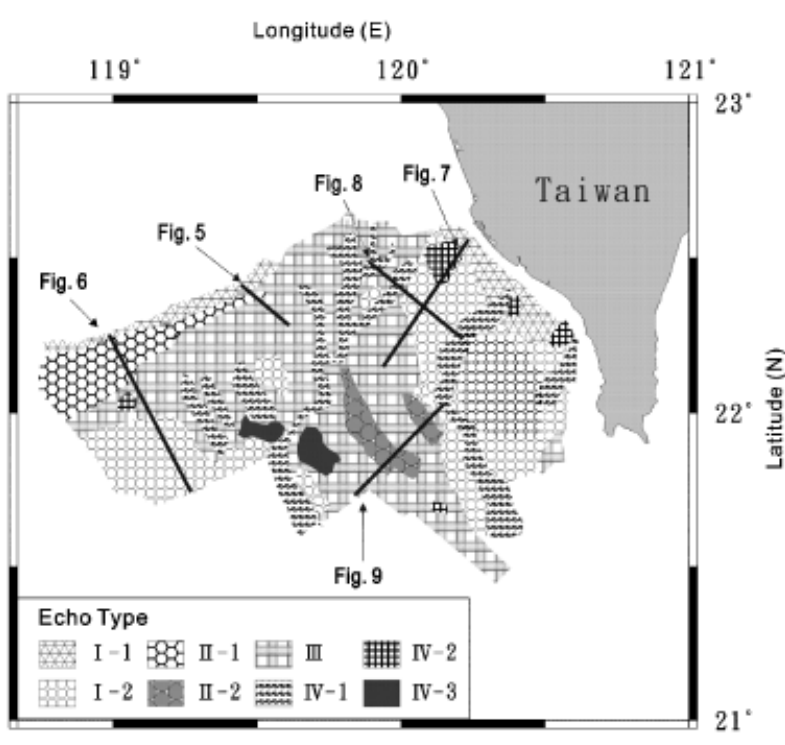

Fig. 10. Distribution of echo types offshore of SW Taiwan. See text for interpretation. Thick lines give the locations of the chirp sonar profiles shown in Figs 5-9.

channels (Figs 5, 8 and 9), indicating frequent slope failures in steep canyon walls. Type IV-2 echoes appear in mud diapir zones where gas-charged sediments and mud volcanoes are observed.

Besides the echo types associated with specific sedimentary processes mentioned above, three main types of echoes are observed in the passive SCS continental slope: types I-2, II-1 and III. Type III echoes are predominant in the continental slope area bordering the orogenic wedge (Figs 5 and 10), but where the continental slope is further away from the Taiwan orogenic wedge, type III echoes occur only in a mid-slope zone (Figs 6 and 10). This distribution pattern correlates well with the sedimentary processes described in the slope failure section below, and many escarpments were observed on the chirp sonar profiles where type III echoes occur. Types II-1 and I-2 echoes are recorded in the western half of the SCS continental margin in the study area (Fig. 10). Type II-1 echoes, which represent mass-transport deposits, most likely creep, occur in the upper slope domain (Figs 5, 6 and 10), whereas type I-2 echoes in the lower slope domain reflect pelagic or hemipelagic deposition (Figs 5 and 10). The distribution pattern of echo type I-2 implies that the lower continental slope is a stable depositional environment.

In the Taiwan orogenic wedge province, the distribution of echo types is more complex (Fig. 10). Apart from the type I-1 echoes along the narrow Kaoping shelf and the echo characters associated with submarine canyons (type IV-1), mud volcanoes (type IV-2) and hard ridge tops (type III), the dominant echoes in the upper Kaoping slope domain are type I-2, whereas the type III echoes are widely distributed in the lower Kaoping slope (Figs 7 and $8-10)$. This distribution pattern contrasts with the passive SCS continental margin where type III echoes are observed on the upper and mid-continental slope
(Figs 5, 6 and 10), whereas the type I-2 echoes are mostly observed on the lower continental slope (Figs 7, 8, and 10). Type II-2 echoes are also found in some of the slope basins on the lower Kaoping slope (Figs 9 and 10) where the sediments are mostly turbidites. Echos of type IV-3 are observed on either side of the deformation front where the Penghu submarine canyon emerges from the fold and thrust zone of the lower Kaoping slope (see Figs 1 and 10).

\section{SEDIMENTARY PROCESSES \\ Slope failures in the passive margin}

Submarine slope failures are observed throughout the passive SCS continental margin. Canyons and gullies formed by mass-wasting processes dissect the upper SCS slope, and generally trend down slope perpendicular to the isobaths. Intercanyon areas form a series of parallel slope ridges (Fig. 3). Slope failures that transport sediments from the shelf and upper slope to deeper environments are key sediment transport processes in the passive SCS continental margin.

Figure 5 presents a dip-oriented chirp sonar and seismic profile across the passive SCS continental margin. A strong Bottom Simulating Reflector (BSR) is clearly visible on the seismic profile, about $300 \mathrm{~ms}$ below the seafloor in the lower part of the continental slope on the seismic profile (Fig. 5c). Slope failures are evident as steep cliffs at the shelf break and at several places along the profile down to $1700 \mathrm{~m}$ water depth. The heights of the cliffs that could be the head scarps or sidewalls of slope failures vary from 10 to over $100 \mathrm{~m}$. Rugged seafloor, where numerous scars and slump deposits lie, presents as small irregular hyperbolic echoes (type III echoes) on the chirp sonar profile.

West of $119^{\circ} 24^{\prime} \mathrm{E}$, most slope failures occur on the middle to lower part of the SCS continental slope. The seafloor is smooth and the gradient is gentle on the upper continental slope (Fig. 6), whereas numerous slope failures are observed below $750 \mathrm{~m}$ water depth. A thin blanketing layer with a transparent zone is observed on the lower part of the upper slope. A small slope failure is observed at about $400 \mathrm{~m}$ water depth on the up-slope side of this thin layer; it may represent slump/debris flow deposits related to the failure. Compared with the profile farther east (Fig. 5), fewer slope failures are identified on this portion of the slope (Fig. 6), and most of the slope failures occur on the mid to lower slope.

Differences in the occurrence of slope failures and seafloor gradients from NE (nearTaiwan) to SW (away from Taiwan) along the passive SCS continental margin may reflect the influence of the impinging Taiwan orogenic wedge on the passive SCS continental margin. We suggest that loading by the orogenic wedge has steepened the continental slope to the east of about $119^{\circ} 24^{\prime} \mathrm{E}$, promoting slope failure and canyon-cutting processes along the shelf edge and in the upper slope area. West of about $119^{\circ} 24^{\prime} \mathrm{E}$, where the SCS continental margin is no longer affected by the 
Taiwan orogenic wedge, slope failures are mostly located in the lower slope area. In fact, in the SCS continental slope away from the Taiwan orogenic wedge, an apparent change of the slope gradient is observed around the $2000 \mathrm{~m}$ isobath. This boundary separates the steeper upper slope domain from the gentler lower slope domain. Mass-wasting processes are mostly erosive in the upper continental slope, as a few or only thin deposits are observed there. In contrast, both chaotic and discontinuous seismic facies interpreted as slump/debris-flow deposits and turbidite deposits with continuous, parallel internal reflectors are observed in the lower continental slope domain where BSRs (e.g. Fig. 5) are frequent (Liu et al., 2006).

\section{Fill-and-spill processes in the orogenic wedge}

Active tectonics are a major control on the sedimentary processes in the submarine Taiwan orogenic wedge. Three large submarine canyons run across the Kaoping shelf and slope (Fig. 1). From east to west, they are the Fangliao canyon (Yu \& Lu, 1995), the Kaoping canyon (Liu et al., 1993) and the Penghu canyon system (Chuang \& Yu, 2002). These submarine canyons have conveyed large amounts of sediments from the Taiwan mountain belt to the deep SCS basin. However, structural lows between imbricated folds and thrusts and diapiric ridges have formed intraslope basins and sediment depocentres on the orogenic wedge. Similar to the intraslope basins of the northern Gulf of Mexico,'fill-and-spill' depositional processes (e.g. Prather et al., 1998; Toniolo et al., 2006a, b) have dominated sediment dispersal during slope development (Chiang et al., 2004; Yu \& Huang, 2006).

Basin fills are characterized by a distinct upward change in seismic facies beginning with a basal, convergentbaselapping facies, succeeded by chaotic facies and topped by parallel and draping facies (Figs 8 and 9). Sediments from the prograding shelf and upper slope are transported and deposited mainly in the confined basal accommodation space of intraslope basins, forming convergentbaselapping seismic facies in the early stage of basin fill. In the later stages of basin development, sediments have been transported to a lower slope distal to the sediment source, progressively filling and spilling intraslope basins in a generally southwestward direction (Yu \& Huang, 2006). These elongated basins parallel the structural trend of the orogenic wedge, and have a high length-to-width ratio.

The 'fill-and-spill' process can be observed on the chirp sonar profiles. Figure 7 shows a chirp sonar profile that runs from the Kaoping shelf to the upper Kaoping slope. Two ridges (labelled A and B) can be identified in the southwestern portion of the profile. Ridge A has acted as a sill that controls the transport direction of the sediments. Influx of sediment from the Taiwan mountain belt into this region via the Kaoping River is extremely high (49 MT/year; Dadson et al., 2003). These sediments have filled the intraslope basin on the NE side of Ridge A, and sediments are now spilling over this ridge and into the in- traslope basin between Ridges A and B (Fig. 7). Slope failures have occurred on the flanks of Ridge $B$ and side walls of the submarine canyon between ridges A and B. Some uppermost transparent layers (type IV-3 echoes) appear to be debris flow deposits, suggesting that the displaced slope sediments travelled relatively short distances.

Along-slope variations of seafloor sedimentary and morphological features are revealed in Fig. 8, where the chirp and seismic profiles show ridges, canyons (Penghu canyon and Kaoping canyon) and an intraslope basin. The seismic image shows that the submarine canyons are bounded by anticlinal ridges, and there is a buried ridge underneath the intraslope basin fill. The thickness of the intraslope basin sediment is more than $2 \mathrm{~s}$ (two-way travel time) on either side of the buried ridge (Fig. 8). On the chirp sonar image, the type I-2 echoes with continuous, parallel internal reflections of the seafloor sediment in the intraslope basin are more than $50 \mathrm{~m}$ deep (Fig. 8). Some of the reflections are deformed by the flanks of the folded ridges, revealing active tectonism in this region.

There are at least four $\mathrm{NW}-\mathrm{SE}$-trending intraslope basins between the Kaoping canyon and the Penghu canyon on the lower Kaoping slope. Sediment transport depends on the submarine canyon and channel systems connecting these basins. Figure 9 presents a chirp sonar profile with the corresponding seismic image of the lower slope domain. Two slope basins near the Kaoping canyon have already been filled with sediment. The third intraslope basin shown at the SW end of the profile (Fig. 9) has an active channel at the foot of a ridge, and the sediment in this basin is much thicker than in the two shallower intraslope basins.

Comparison of the morphology of the canyons at either end of the profile in Fig. 9 shows that the Kaoping canyon has a steep V-shaped cross-profile, whereas the small unnamed submarine canyon in the SW is much wider and shallower. There are slump deposits in the Kaoping canyon observed on the chirp sonar profile, but the Kaoping canyon is mainly erosive at the present time (Fig. 9). On the other hand, there are thick sediments beneath the floor of the small submarine canyon, which implies that part of the sediments transported by turbidity currents along submarine canyons are deposited in the distal slope basins.

\section{DISCUSSION}

\section{The effect of sediment supply}

Sediment supply has a major impact on deposition. Sediment sources are quite different in the two tectonic provinces offshore of SW Taiwan. On the passive SCS continental margin, sediments are mainly terrestrial and biological in origin (Yen \& Lundberg, 2006), and the amount of sediment transported into this region is much less than the supply to the submerged Taiwan orogenic wedge. Although the sediments of the passive SCS conti- 
nental margin mainly come from China, Liu et al. (2008) have shown that a significant portion of the detrital sediment on the SCS continental margin actually came from Taiwan, as similar clay mineral assemblages were observed from the Taiwan orogenic wedge to the northeastern SCS continental margin. This suggests that deep currents have carried re-suspended fine sediments from Taiwan into the northern SCS continental margin, similar to what Ludmann et al. (2005) suggested for the SCS slope of the Dongsha Island region located to the west of the study area. However, sediment waves indicative of these deep bottom currents (Zhong et al., 2007) were not observed in our study area, and downslope processes appear to dominate the SCS continental slope.

In contrast to the SCS passive margin, rapid tectonic uplift and high erosion rates have led to large volumes of sediments from the Taiwan mountain belt being transported into the submarine orogenic wedge region off southern Taiwan since Pliocene times (Covey, 1984; Chiang et al., 2004). Submarine canyons have provided convenient pathways for part of the Taiwan-derived sediments to the deep ocean, whereas the rest of the terrigenous sediments have filled the Kaoping slope basins. This has smoothed the seafloor of the upper Kaoping slope, except where submarine canyons are present. The equilibrium profile of the continental slope is apparent in the upper slope domain of the orogenic wedge. On the other hand, in the SCS continental margin province, due to limited sediment supply, the head scarps of slope failures persist for a long period of time and the slope gradient will increase locally due to slope failure. The gradient map (Fig. 3) shows that the passive SCS margin has a steeper upper slope, whereas the orogenic wedge has a steeper lower slope.

The echo character map (Fig. 10) reflects the gradient changes. The upper Kaoping slope is dominated by continuous and parallel reflections (echo type I-2), especially in the submarine fan that extends from the mouth of the Kaoping River. The seafloor echo characters of the lower Kaoping slope reveal abundant slope failures on the flanks of anticlinal ridges with irregular echoes (type III echoes). The passive SCS continental slope also presents a distinct zonal distribution of erosion and deposition as revealed on the echo character map, but the pattern is opposite to that in the Kaoping slope region: slope failure is the dominant process in the upper SCS continental slope whereas turbidite deposition has shaped on the lower SCS continental slope. Damuth (1980a) placed the boundary separating his echo types $3 \mathrm{~A}$ and $1 \mathrm{~B}$ at about the $2000 \mathrm{~m}$ isobath. It coincides with the boundary we have found here.

\section{Evolution of retrogressive failures}

Along the passive continental slope, the occurrence of echo type III diminishes southwestward (Fig. 10). This suggests that the occurrence of slope failures may follow a trend. Sultan et al. (2004) proposed a model of retrogressive failure of the continental slope when sea level drops, but the tectonics of the SCS continental margin in the study area might be an alternative driver of retrogressive failures. The northeastern corner of the passive SCS continental margin is affected by loading of the Taiwan orogenic wedge (Lin \& Watts, 2002). Extensional crustal deformation has occurred along the continental margin due to lithospheric bending. In this location, the SCS continental slope has steepened here due to the impinging orogenic wedge, and this may have facilitated initial slope failure. Once the initial failure has occurred, the temperature and pressure of the upper part of the sediments will change, leading to a second slope failure. As a consequence, retrogressive slope failures occur progressively, moving their head wall towards the upper part of the slope.

\section{Gas hydrate dissociation effect}

Widely distributed BSR have been observed beneath the seafloor in the offshore area of SW Taiwan (Chi et al., 1998; Liu et al., 2006); very high methane concentrations in the bottom sea water and in the pore fluid of the seafloor sediment have also been measured at many coring sites in the study area (Chuang et al., 2006), suggesting that gas hydrates are present beneath the seafloor. When the climate warms (e.g. in Late Quaternary), gas hydrates in the stability zone could dissociate and produce free gas in the sediment pore space, reducing the strength of the sediments on the upper slope and increasing the probability of slope failures. McAdoo et al. (2000) showed that most of the submarine landslides on the passive US continental margin occurred between the 1000 and $2000 \mathrm{~m}$ isobaths. However, the headwalls of slumps and slides observed in our study area are much shallower. The locations of the slide headwalls are mostly at water depths around $500 \mathrm{~m}$ in the SCS continental margin. This could be explained by reduction of shear strength of sediments due to gas hydrate dissociation at shallower depths within the SCS passive continental margin. However, a direct link between slope failures and gas hydrate dissociation (i.e. seeing the gas) is yet to be observed.

In contrast, in the orogenic wedge province, slope failures that appear most likely to be triggered by gas hydrate dissociation are limited to canyons' walls or steep flanks of some ridges. Although extremely high methane concentrations have been detected in the bottom sea water and in cored sediments offshore SW Taiwan (Chuang et al., 2006; Yang et al., 2006), and gassy sediments are widely distributed in the study area (Chiu et al., 2006), the slope basins separated by NW-SE-trending ridges in the upper Kaoping slope have been filled with sediments to form a gently dipping, smooth seafloor that is not prone to slope failure. Therefore, the effects of gas hydrate dissociation on sedimentary processes in passive and in active margins are somewhat different. 


\section{CONCLUSIONS}

A detailed analysis of chirp sonar data offshore SW Taiwan reveals distinctive echo types that correlate well with local sedimentary features. Eight echo types have been identified based on their clarity, continuity, depth of penetration, bottom and sub-bottom echo geometry, etc. These echo types are grouped into four categories in this study: Type I echoes have distinct seafloor echoes that may or may not show stratified sub-bottom reflectors depending on the grain size of the seafloor sediments; Type II echoes are indistinct echoes that are interpreted to be formed by creep sediments or turbidite deposits; Type III echoes have hyperbolic shapes that reflect hard, irregular or very rough seafloor topography; and Type IV echoes are irregular echoes that represent special sedimentary features such as slope failures, gassy sediments and debris flow deposits.

An echo character map that we compiled in this study reveals different sedimentary processes in the tectonic and depositional environments of the study area. Echo type I-1 occurs on the passive SCS continental shelf and the Kaoping shelf, suggesting that the shelf deposits are mostly coarse-grained sands and silts. Echo type I-2 is observed in the lower SCS continental slope and in the upper Kaoping slope, indicating deposition in those areas. Type II-1 echoes, which represent creep sediments, are observed in the western part of the upper slope domain of the SCS continental margin in our study area, whereas type II-2 echoes, which represent turbidite deposits, appear in the slope basins of the lower Kaoping slope. Type III echoes that suggest either rock outcrops, or very rough seafloor topography, are observed on top of several submarine ridges, and on the upper and mid-slope area of the SCS continental margin and the lower Kaoping slope of the Taiwan orogenic wedge. Type IV-1 echoes that represent slope failures appear along submarine canyons and their tributaries. Type IV-2 echoes that may be associated with gases in the sediments are distributed where submarine mud volcanoes have been observed. Type IV-3 echoes appear along either side of the lower section of the Penghu canyon, indicating the location of massive debris flow deposits there. There is a major difference between the sedimentary environments of the passive SCS continental margin and the submarine orogenic wedge offshore SW Taiwan. The echo distribution map clearly indicates that in the passive SCS continental margin province, the sedimentary environment in the upper to mid-slope is erosional in nature, dominated by downslope processes, whereas the lower continental slope of the SCS continental margin is depositional in nature. On the other hand, in the active submarine Taiwan orogenic wedge, the upper slope domain appears to be a depositional environment, except in submarine canyons, whereas the lower slope domain is erosional in nature, except in slope basins.

The main reason for this huge contrast is the supply of terrigenous sediment. Huge amounts of sediment have been carried into the submarine Taiwan orogenic wedge offshore of SW Taiwan, and fill-and-spill processes have smoothed the seafloor topography of the upper Kaoping slope. In the lower Kaoping slope, spilled sediments have filled only part of the slope basins, and the steep slopes of the ridge flanks and submarine canyon walls generate frequent slope failures. The passive SCS continental margin receives considerably less sediment from either China or Taiwan. There, the steep slope of the upper continental slope forms an erosional environment whereas mass-wasting materials are deposited in the lower continental slope and continental rise, where the seafloor slope is much gentler. The downslope processes are especially active in the eastern half of the SCS continental margin adjacent to the Taiwan orogenic wedge. We suggest that this is due to the effect of orogenic wedge loading, causing extensional structural deformation along this part of the SCS continental margin. The bending and faulting of the continental slope due to orogenic wedge loading may trigger retrogressive failures on the upper continental slope. Away from the orogenic wedge, fewer slope failures have occurred in the SCS continental upper slope domain. Dissociation of gas hydrates that are widely distributed in both the SCS passive continental margin and the active orogenic wedge in the study area could aid the development of slope failures, but their effects must be local, if they exist, as no direct link between gas hydrate dissociation and massive landslides was observed.

\section{ACKNOWLEDGEMENTS}

We would like to thank the Central Geological Survey, Ministry of Economic Affairs, ROC. for organizing and supporting the gas hydrate investigation programme that made this study possible. The chirp sonar and seismic data used in this study were collected by the R/V Ocean Researcher 1 of the Institute of Oceanography, National Taiwan University, with excellent technical support from $S$. D. Chiu. Philippe Schnurle processed the seismic data, and K. R. Lai and S. Y. Liu helped in preparing the chirp sonar data. Swath bathymetry data were collected by the R/ VAtalante during the ACT cruise led by S. Lallemand and C. S. Liu. Critical comments and suggestions made by J.E. Damuth, N. Hovius and J. Malavieille significantly improved this paper. This study is supported by the Central Geological Survey, Ministry of Economic Affairs, ROC under grants 5226902000-05-94-01.

\section{REFERENCE}

Bryant, W.R. \& Roemer, L.B. (1983) Structure of the continental shelf and slope of the northern gulf of Mexico and its geohazards and engineering constrains. In: CRC of Handbook of Geophysical Exploration at Sea (Ed. by R.A. Geyer), pp. 123218. CRC press, Boca Raton, FL.

Casas, D., Ercilla, G., Baraza, J., Alonso, B. \& Maldonada, A. (2003) Recent mass-movement processes on the Ebro continental slope (NW Mediterranean). Mar. Petrol. Geol., 20, 445-457. 
Chen, M.P. (1983) Physical properties and depositional environments of continental slope sediments, southern Taiwan Strait. Acta Oceanogr. Taimanica, 14, 42-63.

Chi, W.C., Reed, D.L., Liu, C.S. \& Lundberg, N. (1998) Distribution of the bottom-simulating reflector in the offshore Taiwan collision zone. Terr. Atmos. Ocean. Sci., 9, 779-794.

Chiang, C.S., Yu, H.S. \& Chou, Y.W. (2004) Characteristics of wedge-top depozone of the southern Taiwan foreland basin. Basin Res., 16, 65-78.

Chiu, J.K., Tseng, W.H. \& Liu, C.S. (2006) Distribution of gassy sediments and mud volcanoes offshore southwest Taiwan. Terr. Atmos. Ocean. Sci., 17, 703-722.

Chough, S.K., Kim, J.W., Lee, S.H., Shinn, Y.J., Jin, J.H., Suh, M.C. \& LEE, J.S. (2002) High-resolution acoustic characteristics of epicontinental sea deposits, central-eastern Yellow Sea. Mar. Geol., 188, 317-331.

Chuang, C.Y. \& YU, H.S. (2002) Morphology and canyon forming processes of upper reach of the Penghu Submarine Canyon off southwestern Taiwan. Terr. Atmos. Ocean. Sci., 13, 91-108.

Chuang, P.C., Yang, T.F., Lin, S., Lee, H.F., Lan, T.F.F., Hong, W.L., Liu, C.S., Chen, J.C. \& Wang, Y. (2006) Extremly high methane concentration in bottom water and cored sediments from offshore southwestern Taiwan. Terr. Atmos. Ocean. Sci., 17, 903-920.

Covey, M. (1984) Lithofacies analysis and basin reconstruction, Plio-Pleistocene western Taiwan foredeep. Petrol. Geol. Taiman, 20, 53-83.

Dadson, S.J., Hovius, N., Chen, H., Dade, W.B., Hiseh, M.L., Willett, S.D., Hu, J.C., Horng, M.J., Chen, M.C., Stark, C.P., Lague, D. \& Lin, J.C. (2003) Links between erosion, runoff variability and seismicity in the Taiwan orogen. Nature, 426, 648-651.

DAmuth, J.E. (1975) Echo character of western equatorial Atlantic floor and its relationship to dispersal and distribution of terrigenous sediments. Mar. Geol., 18, 17-45.

Damuth, J.E. (1979) Migrating sediment waves created by turbidity currents in the northern South China Basin. Geology, 7, 520-523.

Damuth, J.E. (1980a) Quaternary sedimentation processes in the South China Basin as revealed by echo-character mapping and piston-core studies. In: The Tectonic and Geologic Evolution of Southeast Asian Seas and Islands (Ed. by D.E. Hayes), Amer. Geophys. Union Geophys. Monogr., 23, 105-126.

Damuth, J.E. (1980b) Use of high-frequency (3.5-12 kHz) echograms in the study of near-bottom sedimentation processes in the deep sea: a review. Mar. Geol., 38, 51-75.

Damuth, J.E. \& Hayes, D.E. (1977) Echo character of east Brazilian continental-margin and its relationship to sedimentary processes. Mar. Geol., 24, 73-95.

Damuth, J.E., JaCOBI, R.D. \& Hayes, D.E. (1983) Sedimentation processes in the northwest Pacific Basin revealed by echo-character mapping studies. Geol. Soc. Am. Bull., 94, 381-395.

Gaullier, V. \& Bellaiche, G. (1998) Near-bottom sedimentation processes revealed by echo-character mapping studies, northwestern Mediterranean Basin. AAPG Bull., 82, 1140-1155.

Hovius, N., Stark, C.P., Chu, H.T. \& Lin, J.C. (2000) Supply and removal of sediment in a landslide-dominated mountain belt: Central Range, Taiwan. 7. Geol., 108, 73-89.

Huang, C.Y., Wu, W.Y., Chang, C.P., Tsao, S., Yuan, P.B., Lin, C.W. \& XIA, K.Y. (1999) Tectonic evolution of accretionary prism in the arc-continent collision terrane of Taiwan. Tectonophysics, 281, 31-51.
Lallemand, S.E., Liu, C.S. \& The ACT Scientific Crew (1997) Swath bathymetry mapping reveals details of the active arccontinent collision offshore Taiwan. EOS, Trans. AGU, 78, 173-175.

Lee, S.H., Bahk, J.J., Chough, S.K., Back, G.G. \& Yoo, H.S. (2004) Late quaternary sedimentation in the Ulleung Inerplain Gap, East Sea (Korea). Mar. Geol., 206, 225-248.

Lee, S.H., Chough, S.K., Back, G.G. \& Kim, Y.B. (2002) Chirp $(2-7 \mathrm{kHz})$ echo characters of the South Korea Plateau, East Sea: style of mass movement and sediment and sediment gravity flow. Mar. Geol., 184, 227-247.

Lee, S.H., Chough, S.K., Back, G.G., Kim, Y.B. \& Sung, B.S. (1999) Gradual downslope change in high-resolution acoustic characters and geometry of large-scale submarine debris lobes in Ulleung Basin, East Sea (Sea of Japan), Korea. Geo-Mar. Lett., 19, 254-261.

Lee, T.G., Hein, J.R., Lee, K., Moon, J.W. \& Ko, Y.T. (2005) Sub-seafloor acoustic characterization of seamounts near the Ogasawara Fracture Zone in the western Pacific using chirp (3-7 kHz) sub-bottom profiles. Deep-Sea Res. I, 52, 1932-1956.

Lin, A.T., Liu, C.S., Lin, C.C., Schnurle, P., Chen, G.Y., Liao, W.Z., Teng, L.S., Chuang, H.J. \& Wu, M.S. Tectonic features associated with the overriding of an accretionary wedge on top of a rifted continental margin: an example from Taiwan. Mar. Geol., (accepted).

Lin, A.T. \& WatTs, A.B. (2002) Origin of the West Taiwan basin by orogenic loading and flexure of a rifted continental margin. Four. Geophys. Res., 107, B9, 2185, doi: 10.1029/2001JB000669.

LiU, C.S. (2007) Geological exploration of gas hydrate resources offshore southwestern Taiwan - Geophysical investigation (4/ 4). Central Geological Survey Report 96-26 Summary, 176pp. (in Chinese with English abstract)

Liu, C.S., Deffontaines, B., Lu, C.Y. \& Lallemand, S. (2004) Deformation patterns of an orogenic wedge in the transition zone from subduction to collision offshore southwestern Taiwan. Mar. Geophys. Res., 25, 123-137.

Liu, C.S., Huang, I.L. \& Teng, L.S. (1997) Structure features off southwestern Taiwan. Mar. Geol., 137, 305-319.

Liu, C.S., Liu, S.Y., Lallemand, S.E., Lundberg, N. \& Reed, D. (1998) Digital elevation model offshore Taiwan and its tectonic implications. Terr. Atmos. Ocean. Sci., 9, 705-738.

Liu, C.S., Lundberg, N., Reed, D. \& Huang, Y.L. (1993) Morphological and seismic characteristics of the Kaoping Submarine Canyon. Mar. Geol., 111, 93-108.

Liu, C.S., SchnŸrle, P., Wang, Y., Chung, S.H., Chen, S.C. \& Hsiuan, T.H. (2006) Distribution and characters of gas hydrate offshore of southwestern Taiwan. Terr. Atmos. Ocean. Sci., 17, 615-644.

Liu, Z., Tuo, S., Colin, C., Liu, J.T., Huang, C.-Y., Selvaraj, K., Chen, C.-T.A., Zhao, Y., Siringan, F.P., Boulay, S. \& Chen, Z. (2008) Evaluation detrital sediment contribution of Taiwan to the northern South China Sea. Mar. Geol., doi: 10.1016/j.margeo.2008.08.003.

Ludmann, T., Wong, H.K. \& Berglar, K. (2005) Upward flow of North Pacific Deep Water in the northern South China Sea as deduced from the occurrence of drift sediments. Geophys. Res. Lett., 3, L05614, doi: 10.1029/2004GL021967.

MaCDonaLD, D.I.M. (1993) Controls on sedimentation at convergent plate margins. Spec. Publs Int. Ass. Sediment., 20, 225-257.

McAdoo, B.G., Pratson, L.F. \& Orange, D.L. (2000) Submarine landslide geomorphology, US continental slope. Mar. Geol., 169, 103-136.

Mienert, J. \& Weaver, P, Eds. (2003) European Margin Sediment Dynamics. Springer-Verlag, Berlin, 309pp. 
Orpin, A.R. (2004) Holocene sediment deposition on the poverty-slope margin by the muddy Waipaoa River, East Coast New Zealand. Mar. Geol., 209, 69-90.

Prather, B.E., Booth, J.R., Steffens, G.S. \& Craig, P.G. (1998) Classification, lithologic calibration, and stratigraphic succession of seismic facies of intraslope basins, deep-water Gulf of Mexico. AAPG Bull., 82, 701-728.

Reed, D.L., Lundberg, N., Liu, C.S. \& Kuo, B.Y. (1992) Structural relations along the margins of the offshore Taiwan accretionary wedge; implication for accretion and crustal kinematics. Acta Geol. Taiman., 30, 105-122.

Shinn, Y.J., Chough, S.K., KIM, J.W. \& WpP, J. (2007) Development of depositional systems in the southeastern Yellow Sea during the postglacial transgression. Mar. Geol., 239, 59-82.

Sultan, N., Cochonat, P., Foucher, J.P. \& Mienert, J. (2004) Effect of gas hydrate melting on seafloor slope instability. Mar. Geol., 213, 379-401.

Sun, S.I. \& Liu, C.S. (1993) Mud diapirs and submarine channel deposits in offshore Kaohsiung-Hengchun, southwest Taiwan. Pet. Geol. Taiman, 28, 1-14.

Teng, L.S. (1990) Geotectonic evolution of late Cenozoic arccontinent collision in Taiwan. Tectonophysics, 183, 57-76.

Toniolo, H., Lamb, M. \& Parker, G. (2006a) Depositional turbidity currents in diapiric minibasins on the continental slope: formulation and theory. 7. Sediment. Res., 76, 783-797.

Toniolo, H., Parker, G., Voller, V. \& Beauboeuf, R. (2006b) Depositional turbidity currents in diapiric minibasins on the continental slope: experiments - numerical simulation and upscaling. F. Sediment. Res., 76, 798-818.

Wessel, P. \& Sмith, W.H.F. (1993) The GMT-system version 2.1.4. Technical reference and Cookbook, SOEST/NOAA.

Whitmore, G.P., Crook, K.A.W. \& Johnson, D.P. (1999) Sedimentation in a complex convergent margin: the Papua New
Guinea collision zone of the western Solomon Sea. Mar. Geol., $157,19-45$.

Yang, T.F., Chuang, P.C., Lin, S., Chen, J.C., Wang, Y. \& Chung, S.H. (2006) Methane venting in gas hydrate potential area offshore of SW Taiwan: evidence of gas analysis of water column samples. Terr. Atmos. Ocean. Sci., 17, 933-950.

Yen, J.Y. \& Lundberg, N. (2006) Sediment compositions in offshore southern Taiwan and their relations to the source rocks in modern arc-continent collision zone. Mar. Geol., 225, 247-263.

Yu, H.S. \& HuAng, Z.Y. (2006) Intraslope basin facies and sedimentary processes in the Kaoping slope, offshore southwestern Taiwan. Terr. Atmos. Ocean. Sci., 17, 659-677.

YU, H.S. \& LEE, J.T. (1992) Echo character of the shelf-upper slope transition off southwestern Taiwan margin and it's relationship to Quaternary sedimentation. Acta Oceangr. Taiman., 29, 45-58.

Yu, H.S. \& Lu, J.C. (1995) Development of the shale diaper-controlled fangliao canyon on the continental-slope off southwestern Taiwan. 7. Southeast Asian Earth Sci., 11, 265-276.

YU, H.S. \& SoNG, G.S. (2000) Submarine physiographic features in Taiwan region and their geological significance. 7. Geol. Soc. China, 43, 267-286.

YU, H.S. \& WEN, Y.H. (1992) Physiographic characteristics of the continental margin off southwestern Taiwan. 7. Geol. Soc. China, 35, 337-351.

Zhong, G., LI, Q., Hao, H. \& WANG, L. (2007) Current status of deep-water sediment wave studies and the South China Sea perspectives. Adv. Earth Sci., 22, 907-913 (in Chinese with English abstract).

Manuscript received 17 fune 2008; Manuscript accepted 9 September 2008 